\title{
David Ingersoll, Behavioralism and the Modern Revival of Legal Realism
}

\author{
Thom Brooks \\ Durham Law School, Durham University, Durham, UK \\ Email: thom.brooks@durham.ac.uk
}

Received 13 May 2015; accepted 9 August 2015; published 12 August 2015

Copyright (C) 2015 by author and Scientific Research Publishing Inc.

This work is licensed under the Creative Commons Attribution International License (CC BY). http://creativecommons.org/licenses/by/4.0/

(c) (i) Open Access

\begin{abstract}
David Ingersoll's essay “Karl Llewellyn, American Legal Realism and Contemporary Legal Behavioralism" is a significant, but neglected contribution to our understanding of legal realism in the United States. This article argues that it first anticipates the shape of legal realism's revival today and shows that Ingersoll was ahead of his time. The once dominant school of legal realism had become a much maligned theory of law when this essay was first published. Ingersoll identifies two varieties of legal realism and most critics focus on only one of them. He argues that legal realism should be revived if it develops its second variety often overlooked which accepts rule skepticism and recognizes the importance of social psychology to predicting legal outcomes more reliably.
\end{abstract}

\section{Keywords}

Behavioralism, Ingersoll, Legal Realism, Leiter, Llewellyn, Rule Skepticism, Social Psychology

\section{Introduction}

David Ingersoll's essay “Karl Llewellyn, American Legal Realism and Contemporary Legal Behavioralism” is a significant, but neglected contribution to our understanding of legal realism in the United States that anticipates the shape of its revival today (Ingersoll, 1966). Legal realism was a much maligned theory of law when this essay was published in 1966 (Bin, 1991; Fisher, Horwitz, \& Reeed, 1993; Zaremby, 2015). Once as the dominant approach earlier that century, legal realism became an object of serious criticisms and most of its leading figures have died, such as Jerome Frank in 1957 and Karl Llewellyn in 1962. The question was whether legal realism would die with them and become a topic of primarily historical interest.

Legal realism was "an attempt to inject the methodological rigor and 'spirit of scientific investigation' into a study of law dominated by deductive logic, a rather stringent conception of precedent, and a mechanical notion of judicial function” (Ingersoll, 1966: p. 253). Realists understood judicial behavior using insights derived from 
the social sciences like economics and sociology to predict judicial outcomes (Schlegel, 1995). Their claims were limited to some degree by the current state of the social science it was built on, but it represented a genuinely radical departure from the orthodoxy that legal rules alone determined legal outcomes and not influenced by other factors (Paul, 1959).

This article argues that legal realism came to be dominated by a particular view of legal realism associated with contributions by Jerome Frank. It is this view that has attracted the most criticisms. Ingersoll was correct to see the possibility of legal realism's revival in identifying a second way we can and should understand legal realism that moves us away from Frank's problematic conception and anticipates later work by Brian Leiter that has done so much now to popularize legal realism today.

This article begins by examining Frank's understanding of legal realism. It is argued that Frank develops a view of legal realism as "fact skepticism" which is problematic. The following section considers an alternative way of understanding legal realism presented by Karl Llewellyn where legal realism is seen as a kind of "rule skepticism". The article concludes by claiming that Ingersoll identifies these two different understandings of legal realism and he argues that the latter by Llewellyn is more promising. This view of legal realism as rule skepticism is adopted by leader legal realists today like Leiter, but without explicit acknowledgement of Ingersoll's contributions.

\section{The Problem with the Frankification of Legal Realism}

Jerome Frank was a central figure in legal realism whose writings exerted tremendous influence on how it was perceived by opponents. Most commentators viewed Frank's understanding of legal realism as definitive (Ingersoll, 1966: p. 254). This "Frankification" of realist doctrine is a problem because it obscures its future promise (Leiter, 2007: p. 17).

Legal realism is traditionally associated with "fact skepticism” (Paul, 1959). Realists like Frank reject the idea that the facts of a case can be objective. He says: "The 'facts', it must never be overlooked, are not objective. They are what the judge thinks they are. And what he thinks they are depends on what he hears and sees as the witnesses testify — which may not be what another judge would hear and see” (Frank, 1949: p. 55). The facts of a case are held to be "facts" not because they are true in actual fact, but because they are confirmed as true by a court (Frank, 2008).

Frank's approach is widely rejected. Ingersoll argued that Frank's fact skepticism faces a serious problem. Fact skeptics are concerned with the problems that human perception can contribute to the administration of justice, but this may entail a rejection of legal precedent (Ingersoll, 1966: p. 256). This is because if legal facts are in the eyes of the beholder differing from one courtroom to the next then "stare decisis is relatively useless in that it presupposes the existence of similar situation types. Thus, the fact skeptic is questioning the possibility of justice obtaining at all within any legal system based upon a notion of controlling precedent” (Ingersoll, 1966: p. 256).

\section{A Second Variety of Legal Realism}

Ingersoll argues that Frank's fact skepticism is not the only kind of legal realism. A second variety supports "rule skepticism": instead of denying the existence of facts, rule skeptics focus on the application of rules and they are doubtful about whether their application is a determining factor of any single, or "correct", outcome.

This is exemplified in the work of Karl Llewellyn, who claimed the study of law "deals not with words, but with practice, not with paper theory, but with living fact” (Llewellyn, 2008: p. 8). The problem for the traditional doctrine of precedent is "not [that] paper rules were incorrect but because they contained only a partial truth" (Ingersoll, 1966: p. 257). Legal rules guide judicial behavior, but its study can reveal generalizations that more accurately describe judicial outcomes than the application of rules alone. Therefore, rule skeptics are concerned "with discovering ways by which uniformities in judicial behavior may be discovered" (Ingersoll, 1966: p. 257). They reject the more pessimistic view of fact skeptics like Frank who deny the possibility of uniformity.

Ingersoll's distinction of two kinds of legal realism—Frank's fact skepticism versus Llewellyn's rule skepticism-is important because it anticipates the revival of legal realism and the form it adopted in its attempts to reclaim its once dominant position. Ingersoll rejects Frank's fact skepticism and concedes the criticisms of it. However, Ingersoll argues that legal realism can be rescued if we defend its rule skepticism approach. This can help reveal greater regularity in predicting and explaining judicial outcomes by forcing us to focus on the appli- 
cation of legal rules and how they should be understood. He recommends the behavioralism of social psychology as especially relevant to this project.

Brian Leiter has revitalized our understanding of jurisprudence today and he is the leading contemporary figure working in legal realism now. He has forcefully argued that the "Frankification" of legal realism inflicted long term damage by contributing to its fall from dominance, leading to H. L. A. Hart's famous critique in The Concept of Law that "rendered Realism a philosophical joke in the English-speaking world" (Leiter, 2007: pp. 17-18). Leiter defends a "philosophical reconstruction of Legal Realism" where it is centrally concerned with what judges do (Leiter, 2007: pp. 19, 21). He calls for a "naturalized jurisprudence" that is connected with social sciences like psychology and experimental philosophy to provide "satisfactory predictors of legal outcomes" (Leiter, 2007: pp. 40-41).

These moves towards legal realism's revived respectability today by Leiter follow the path first set out by Ingersoll in 1966. Furthermore, this earlier work receives no mention in legal realism's revival. Sometimes the wheel must be reinvented and it can only be wondered whether legal realism might have held dominance for much longer than it has if Ingersoll's contributions were acknowledged at that time in the mid-1960s.

\section{Conclusion}

Ingersoll's essay commands wider attention because of its almost prophetic insights into how legal realism should be revived that anticipates Leiter's reconstruction decades later, and it shares Leiter's passion for philosophy informed by social sciences like social psychology. Ingersoll's presentation may lack the greater sophistication of Leiter's account and its understanding of legal realism's relation to legal positivism (Leiter, 2001; Brooks, 2012). Nonetheless, Ingersoll provides us with a philosophical account of an important debate that was ahead of its time.

\section{References}

Bin, F. (1991). Legal Realism. Beijing: Law Press.

Brooks, T. (2012). Punishment. London: Routledge. http://dx.doi.org/10.1017/upo9780748631179.006

Fisher, W., Horwitz, M., Reed, T. (ed.) (1993). American Legal Realism. Oxford: Oxford University Press.

Frank, J. (1949). Courts on Trial: Myth and Reality in American Justice. Princeton, NJ: Princeton University Press.

Frank, J. (2008). Law and the Modern Mind. New York: Transaction.

Ingersoll, D. E. (1966). Karl Llewellyn, American Legal Realism and Contemporary Legal Behavioralism. Ethics, 76, 253266. http://dx.doi.org/10.1086/291595

Leiter, B. (2001). Legal Realism and Legal Positivism Reconsidered. Ethics, 111, 278-301. http://dx.doi.org/10.1086/233474

Leiter, B. (2007). Naturalizing Jurisprudence: Essays on Legal Realism and Naturalism in Legal Philosophy. Oxford: Oxford University Press. http://dx.doi.org/10.1093/acprof:oso/9780199206490.001.0001

Llewellyn, K. (2008). The Bramble Bush: The Classic Lectures on the Law and Law School. Oxford: Oxford University Pres.

Paul, J. (1959). The Legal Realism of Jerome N. Frank: A Study of Fact-Skepticism and the Judicial Process. Dordrecht: Springer. http://dx.doi.org/10.1007/978-94-011-9493-8

Schlegel, J. (1995). American Legal Realism and Empirical Social Science. Chapel Hill, NC: University of North Carolina.

Zaremby, J. (2015). Legal Realism and American Law. London: Bloomsbury Academic. 